\title{
Predictive Factors of High-Risk Events for Virological Failure in HIV/AIDS Patients Receiving Long-Term Antiviral Therapy
}

\section{Shanfang Qin}

Longtan Hospital of Guangxi Zhuang Autonomou Region

Jingzhen Lai

Guangxi Medical University

\section{Hong Zhang}

Guangxi Medical University

\section{Di Wei}

Longtan Hospital of Guangxi Zhuang Autonomous Region

\section{Qing Lv}

Longtan Hsopital of Guangxi Zhuang Autonomous Region

\section{Xue Pan}

Longtan Hospital of Guangxi Zhuang Autonomous Region

\section{Lihua Huang}

Longtan Hospital of Guangxi Zhuang Autonomous Region

\section{Ke Lan}

Longtan Hospital of Guangxi Zhuang Autonomous Region

\section{Zhihao Meng}

Longtan Hospital of Guangxi Zhuang Autonomous Region

Hao Liang

Guangxi Medical University

Chuanyi Ning ( $\square$ ningchuanyi@126.com )

Guangxi Medical University https://orcid.org/0000-0002-8748-2780

\section{Research article}

Keywords: HIV, AIDS, ART, Virological failure, viral load

Posted Date: January 27th, 2021

DOI: https://doi.org/10.21203/rs.3.rs-153807/v1 
License: (c) (i) This work is licensed under a Creative Commons Attribution 4.0 International License. Read Full License 


\section{Abstract}

Background: In the era of anti-retroviral therapy (ART), the plasma HIV viral load (VL) is an important primary indicator for monitoring the HIV treatment response. To optimize the clinical management of HIV/AIDS patients, we investigated VL high-risk events related to virological failure (VF) and further explored the preventive factors of high-risk events.

Methods: The data were derived from China's HIV/AIDS Comprehensive Response Information Management System. HIV patients who initiated or received ART in Guangxi between 2003 and 2019 were included. The contributions of VL after 6 months of ART to VF and AIDS-related death were analysed by Kaplan-Meier curves, log-rank tests and Cox regression analyses. Both descriptive analyses and bivariate logistic regression were employed to further explore the preventive factors related to high-risk events of VF.

Results: The cumulative rates of VF in the high low-level viremia group $\left(\chi^{2}=18.45 ; P<0.001\right)$ and nonsuppressed group $\left(\chi^{2}=82.99 ; P<0.001\right)$ were significantly higher than those in the viral suppression (VS) group. Compared with the VS group, the adjusted hazard risk was $7.221(95 \% \mathrm{Cl} .2 .668 ; 19.547)$ in the high LLV group and 8.351 (95\% Cl: $4.253 ; 16.398)$ in the non-suppressed group. Compared with single patients, married or cohabiting $(A O R=0.591 ; 95 \% \mathrm{Cl} .0 .408,0.856)$ and divorced or separated $(A O R=$ $0.425,95 \% \mathrm{Cl}$. $0.207,0.873)$ patients were negatively associated with high-risk events. So were patients acquired HIV homosexually $(A O R=0.572 ; 95 \% \mathrm{Cl}$ : $0.335,0.978)$. However, patients who had ART modification were 1.728 times (95\% Cl: $1.093,2.732)$ more likely to have high-risk events, and patients who used cotrimoxazole during ART were 1.843 times $(95 \% \mathrm{Cl}$. 1.271, 2.672) more likely to have high-risk events.

Conclusions: A VL greater than 200 copies/ml is a high-risk event for VF. Intervention measurements should be adopted to optimize the surveillance of ART in patients who are single or widowed, who have ART modification, and who use cotrimoxazole during ART.

\section{Background}

Human immunodeficiency virus (HIV) infection and acquired immunodeficiency syndrome (AIDS) are threats to public health worldwide. The World Health Organization (WHO) estimated that 38 million individuals worldwide were living with HIV by the end of 2019 ${ }^{[1]}$, and nearly 1.7 million of them were new HIV infections ${ }^{[2]}$. Fortunately, antiretroviral therapy (ART) is implemented to treat HIV-1 infection and improve the life expectancy of HIV/AIDS patients. To mark the roadmap to the elimination of the AIDS epidemic as a public health threat by $2030^{[3]}$, the Joint United Nations Programme on HIV and AIDS (UNAIDS) set the global targets to have $90 \%$ of all HIV-infected individuals being diagnosed, $90 \%$ of those diagnosed being on ART and $90 \%$ of those on ART achieving viral suppression by 2020 (90-90-90 goal). However, only $67 \%$ of individuals living with HIV received ART by the end of 2019 , as estimated by the $\mathrm{WHO}^{[4]}$. At the beginning of 2021, the 90-90-90 goal has fallen short. 
Since the first ART drug was approved, the survival of ART-treated individuals living with HIV has improved because the developed ART regimens reduced HIV viral loads and delayed disease progression. Combination ART was developed to substantially arrest viral replication by targeting and interrupting different stages of the virus life cycle ${ }^{[5,6]}$. As recommended by WHO, ART should be administered to all individuals as early as possible following the HIV diagnosis. The rapid popularisation of ART to treat HIV infection in low- and middle-income countries has successfully saved millions of lives ${ }^{[7,8]}$.

Adhering to the ART regimen is crucial to achieve and maintain viral suppression to prevent further HIV transmission and the progression of HIV infection ${ }^{[9,10]}$. Furthermore, adherence to ART over $95 \%$ of the time is required to achieve full viral load suppression. When patients fail to attain the required adherence level, they may be subjected to a poorer prognosis, higher morbidity and mortality, and the development of resistance to ART ${ }^{[11,12]}$. However, adherence to ART can only be measured by patients' self-report, rather than an objective index. Therefore, monitoring adherence to ART for ART-experienced patients is challenging.

In clinical practice, the plasma HIV viral load (VL) is an important and primary indicator to monitor the HIV treatment response. Additionally, VL can indicate adherence to ART by showing the therapeutic response. According to the China National Handbook on Free Anti-retroviral Therapy for AIDS (4th edition), two consecutive confirmed viral loads $>400$ copies $/ \mathrm{ml}$ after 24 weeks of ART could be defined as virological failure (VF ${ }^{[13]}$. However, there are different definitions of VF. According to the Department of Health and Human Services (DHHS, USA) guidelines, a confirmed viral load $>200$ copies $/ \mathrm{ml}$ can be defined as virological failure $(\mathrm{VF})^{[14]}$. Viral suppression $(\mathrm{VS})$ is achieved if the plasma HIV-1 VL cannot be detected by routine assays ( $<20-50$ copies $/ \mathrm{ml})$. There is a "grey zone" between the VF and VS, usually known as low-level viremia (LLV). Persistent LLV may contribute to an increased risk of VF. A large study in South Africa reported that LLV is not only a risk factor for VF but also decreases the durability of viral resuppression ${ }^{[15]}$. Additionally, drug resistance, immunological failure, non-AIDS comorbidities, clinical progression to AIDS and AIDS-related death were correlated with LLV ${ }^{[16]}$. Therefore, LLV is likely a risk factor resulting in adverse clinical outcomes for HIV/AIDS patients. The occurrence of LLV should be prevented if possible. However, no general agreement exists regarding a standard definition of LLV.

To optimize the clinical management of HIV/AIDS patients, we investigated the risk events related to VF and AIDS-related death based on the data of patients who initiated or received ART in Guangxi between 2003 and 2019 exported from China's HIV/AIDS Comprehensive Response Information Management System (CRIMS). Furthermore, to prevent risk events as early as possible and block the occurrence of subsequent adverse events during ART, we explored the preventive factors of risk events.

\section{Methods}

\section{Study design and population}


A retrospective follow-up study was conducted among HIV/AIDS patients who initiated or received ART in Guangxi, China between 2003 and 2019. We utilized data from China's HIV/AIDS CRIMS. The patients' inclusion criteria were as follows: a) available baseline VL data before treatment initiation; b) ART for 6 months and longer; c) two or more viral load records during follow-up; and d) the interval between viral load tests not exceeding 12 months. Figure 1 shows a flowchart of the patients' inclusion criteria.

\section{Definitions And Data Collection}

Demographic information was collected from the baseline of ART initiation, such as sex, marital status, age at HIV diagnosis, age at ART initiation and registered permanent residence. At ART initiation, HIV infection-related information was also collected, such as the transmission route, Mycobacterium tuberculosis (Mtb) infection in the recent year, opportunistic infections (Ols) in the recent three months, AIDS-related symptoms, WHO clinical stage, and VL. VL, duration on ART (months), ART regimen and ART regimen modification or interruption during the ART follow-up were collected. Based on the 4th edition of the China National Handbook of Free Antiviral Therapy for AIDS, VF was defined as a viral load greater than 400 copies/ml two or more consecutive times during ART, whereas VS was defined as a VL below the minimum detection threshold of the detection reagent (usually below $20 \mathrm{copies} / \mathrm{ml}$ ). VLs between 20 copies/ml and 400 copies/ml were divided into two subgroups: low LLV (20 copies/ml $\leq \mathrm{VL} \leq 200$ copies/ml) and high LLV (200 copies/ml < VL $\leq 400$ copies/ml).

\section{Statistical analysis}

To determine the contribution of VL after 6 months of ART to VF and AIDS-related death, the cumulative rates of VF and AIDS-related death were evaluated by Kaplan-Meier curves and tested by the log-rank test. Cox regression analyses were performed to investigate whether different VLs were associated with VF. Hazard ratios were adjusted for demographic information, HIV infection-related information and ART follow-up data. To further explore the preventive factors related to high-risk events of VF, patients after antiviral therapy were divided into two groups: patients who experienced high-risk events of VF (HR) and those who did not (non-HR). Demographic information, HIV infection-related information and ART followup data were compared between these groups by chi-square test, $t$-test or the Mann-Whitney $U$ test. Variables significantly different between the groups were further entered into a bivariate logistic regression model to identify independent factors correlated with LLV occurrence. All statistical analyses were performed using IBM SPSS statistics 23.0 (IBM Corp, Armonk, NY, USA). All the tests were two-sided, and $P<0.05$ was considered to be significant.

\section{Results}

\section{Incidence of VF and AIDS-related death}


We recruited $1860 \mathrm{HIV}$-infected patients based on the inclusion criteria. They were followed up for a total of 6455.34 person years. After 6 months of ART, VF and AIDS-related death were set as the outcome indicators when following HIV patients. Additionally, the VL between 6-month ART and VF was recorded. Patients were divided into four groups based on the recorded $\mathrm{VL}$, including the viral suppression group (VS; VL $<20$ copies/ml), low LLV group (20 copies/ml $\leq \mathrm{VL} \leq 200$ copies $/ \mathrm{ml}$ ), high LLV group (200 copies/ml $<\mathrm{VL} \leq 400$ copies/ml), and non-suppressed group (VL $>400$ copies/ml).

The cumulative rates of VF and AIDS-related death were calculated by Kaplan-Meier analysis and were further compared among groups by log-rank tests. The cumulative incidence rates of VF and AIDS-related death were significantly different among the four groups $(P<0.001 ;$ Fig. 2$)$. The difference in the cumulative rate of VF between the VS and low LLV groups was insignificant $\left(\chi^{2}=1.921 ; P=0.166\right)$. However, the cumulative rates of VF in the high LLV group $\left(\chi^{2}=18.45 ; P<0.001\right)$ and non-suppressed group $\left(\chi^{2}=82.99 ; P<0.001\right)$ were significantly higher than those in the VS group. The cumulative incidence of AIDS-related death was highest in the high LLV group (Fig. 2b). Furthermore, the cumulative incidence of AIDS-related death in the high LLV group was significantly higher than that in the VS group $\left(\chi^{2}=15.51 ; P<0.001\right)$ and low LLV group $\left(\chi^{2}=8.061 ; P=0.0045\right)$. However, no significant difference was found in the cumulative incidence of AIDS-related death between the high LLV and non-suppressed group $\left(\chi^{2}=2.115 ; P=0.1459\right)$.

Univariate and multivariate Cox regression models were used to determine the effect of VL after 6 months of ART on VF. Compared with the VS group, the adjusted hazard risk was $7.221(95 \% \mathrm{Cl}: 2.668,19.547)$ in the high LLV group and 8.351 (95\% Cl: $4.253,16.398)$ in the non-suppressed group (Table 1). In this study, we supposed that a VL greater than 200 copies/ml after 6 months of ART (high LLV group and nonsuppressed group) is an independent high-risk event for VF.

To prevent VF at an early stage, the independent risk factors for patients who had a VL greater than 200 copies/ml after 6 months of ART were explored. Patients included in this study were divided into a highrisk group and a non-high-risk group based on VL after 6 months of ART. The high-risk group (HR) comprised patients who had a VL greater than 200 copies/ml after 6 months of ART, while the non-highrisk group (non-HR) comprised patients whose VL was not greater than $200 \mathrm{copies} / \mathrm{ml}$ after 6 months of ART. 
Table 1

Effect of the viral load on virological failure after 6 months of ART

\begin{tabular}{|c|c|c|c|c|}
\hline \multirow[t]{2}{*}{ VL after 6 months of ART } & \multicolumn{2}{|l|}{ Univariable analysis } & \multicolumn{2}{|l|}{ Multivariable analysis } \\
\hline & Crude HR $(95 \% \mathrm{Cl})$ & $P$ & Adjusted HR (95\% Cl) & $P$ \\
\hline VS & 1 & $<0.001$ & 1 & $<0.001$ \\
\hline Low LLV & $1.608(0.820,3.153)$ & 0.167 & $1.516(0.723,3.180)$ & 0.271 \\
\hline High LLV & $5.989(2.377,15.091)$ & $<0.001$ & $7.221(2.668,19.547)$ & 0.005 \\
\hline Non-suppressed & $9.717(5.351,17.646)$ & $<0.001$ & $8.351(4.253,16.398)$ & $<0.001$ \\
\hline \multicolumn{5}{|c|}{$\begin{array}{l}\text { a. HR was adjusted by sex, marital status, age when HIV infection was confirmed and ART initiation, } \\
\text { transmission route, TB infection in the recent year at baseline, opportunistic infection in the last } 3 \\
\text { months at baseline, HIV symptoms, clinical stage, CD } 4+\text { T-cell count, VL at baseline, time between HIV } \\
\text { diagnosis and ART initiation, ART modification, times of ART modification, ART interruption and } \\
\text { cotrimoxazole usage before and during ART. }\end{array}$} \\
\hline
\end{tabular}

\section{Demographic Characteristics Of The High-risk Group}

According to the sociodemographic characteristics of the patients at baseline, most were male $(70.70 \%)$ and married or cohabiting (56.88\%), with a median age at the HIV diagnosis of 39 years and a median age at ART initiation of 40 years. Sex and age at HIV diagnosis and ART initiation were not significantly different between the HR and non-HR groups. However, compared with the non-HR group, the marital status of the HR group was significantly different $\left(\chi^{2}=10.812 ; P=0.029 ;\right.$ Table 2$)$. 
Table 2

Baseline demographic characteristics of ART-treated HIV/AIDS patients in Guangxi between 2003 and 2019

\begin{tabular}{|c|c|c|c|c|c|}
\hline Variables & Total (\%) & $\mathrm{HR}(\%)$ & non-HR (\%) & $x^{2} / Z$ & $P$ \\
\hline Sex & & & & 1.556 & 0.212 \\
\hline Male & $\begin{array}{l}1315 \\
(70.70)\end{array}$ & $162(74.31)$ & $\begin{array}{l}1153 \\
(70.22)\end{array}$ & & \\
\hline Female & $545(29.30)$ & $56(25.69)$ & $\begin{array}{l}489 \\
(29.78)\end{array}$ & & \\
\hline Marital status & & & & 10.812 & 0.029 \\
\hline Single & $532(28.60)$ & 68 (31.19) & $\begin{array}{l}464 \\
(28.26)\end{array}$ & & \\
\hline Married or cohabiting & $\begin{array}{l}1058 \\
(56.88)\end{array}$ & $112(51.38)$ & $\begin{array}{l}946 \\
(57.61)\end{array}$ & & \\
\hline Divorced or separated & $132(7.10)$ & $12(5.50)$ & $120(7.31)$ & & \\
\hline Widowed & $132(7.10)$ & $24(11.01)$ & $108(6.58)$ & & \\
\hline Unknown & $6(0.32)$ & $2(0.92)$ & $4(0.24)$ & & \\
\hline $\begin{array}{l}\text { Age at HIV diagnosis (years) } \\
\text { (Median, IQR) }\end{array}$ & $39(29,53)$ & $\begin{array}{l}40(29.75 \\
55.25)\end{array}$ & $\begin{array}{l}39(29 \\
52.25)\end{array}$ & -1.014 & 0.311 \\
\hline $\begin{array}{l}\text { Age at ART initiation (years) } \\
\text { (Median, IQR) }\end{array}$ & $40(30,53)$ & $41(30,56)$ & $40(30,53)$ & -1.066 & 0.286 \\
\hline Total & $\begin{array}{l}1860 \\
(100.00)\end{array}$ & $218(11.72)$ & $\begin{array}{l}1642 \\
(88.28)\end{array}$ & & \\
\hline
\end{tabular}

\section{Hiv Infection Characteristics Of The High-risk Group}

Most of the included patients were infected by HIV heterosexually. However, the HIV transmission routes of patients in the HR group were significantly different from those in the non-HR group $\left(\chi^{2}=10.158 ; P=\right.$ 0.038). The rate of Ols in the last 3 months in the HR group was significantly higher than that in the nonHR group $\left(43.12 \%\right.$ vs $\left.30.02 \% ; \chi^{2}=15.511 ; P<0.001\right)$. Most of the patients were WHO stage I (Table 3 ). However, a significant difference was found in the WHO clinical stage between the HR and non-HR groups $(P=0.015)$. Additionally, the $\mathrm{CD} 4^{+} \mathrm{T}$-cell count of the HR group was significantly lower than that of the non-HR group $(P<0.001)$, while the VL at baseline of the HR group was much higher than that of the nonHR group $(P=0.001)$. However, no significant difference was found in the rates of Mtb infection in recent years, positive AIDS-related symptoms or cotrimoxazole use before baseline between the HR and non-HR groups. 
Table 3

Characteristics of HIV infection of HIV/AIDS patients treated with ART in Guangxi between 2003 and 2019

\begin{tabular}{|c|c|c|c|c|c|}
\hline Variables & Total (\%) & HR (\%) & non-HR (\%) & $x^{2} / z$ & $P$ \\
\hline Transmission route & & & & 10.158 & 0.038 \\
\hline Heterosexual & $\begin{array}{l}1438 \\
(77.31)\end{array}$ & $176(80.73)$ & $\begin{array}{l}1262 \\
(76.86)\end{array}$ & & \\
\hline $\begin{array}{l}\text { Intravenous drug use or blood } \\
\text { exchange }\end{array}$ & $53(2.85)$ & $11(5.05)$ & $42(2.56)$ & & \\
\hline Homosexual & $308(16.56)$ & $24(11.01)$ & $284(17.30)$ & & \\
\hline Vertical & $7(0.38)$ & $0(0.00)$ & $7(0.43)$ & & \\
\hline Unknown & $54(2.90)$ & $7(3.21)$ & $47(2.86)$ & & \\
\hline Mtb infection in the recent year & & & & 5.007 & 0.082 \\
\hline Yes & $164(8.82)$ & $28(12.84)$ & $136(8.28)$ & & \\
\hline No & $\begin{array}{l}1680 \\
(90.32)\end{array}$ & $188(86.24)$ & $\begin{array}{l}1492 \\
(90.86)\end{array}$ & & \\
\hline Unknown & $16(0.86)$ & $2(0.92)$ & $14(0.85)$ & & \\
\hline Ols in the recent 3 months & & & & 15.511 & $\dot{0} 001$ \\
\hline Yes & $587(31.56)$ & $94(43.12)$ & $493(30.02)$ & & \\
\hline No & $\begin{array}{l}1244 \\
(66.88)\end{array}$ & $122(55.96)$ & $\begin{array}{l}1122 \\
(68.33)\end{array}$ & & \\
\hline Unknown & $29(1.56)$ & $2(0.92)$ & $27(1.64)$ & & \\
\hline AIDS-related symptoms & & & & 0.532 & 0.466 \\
\hline Yes & $252(13.55)$ & $33(15.14)$ & 219 (13.34) & & \\
\hline No & $\begin{array}{l}1608 \\
(86.45)\end{array}$ & $185(84.86)$ & $\begin{array}{l}1423 \\
(86.66)\end{array}$ & & \\
\hline WHO clinical stage & & & & 10.499 & 0.015 \\
\hline I & $\begin{array}{l}1068 \\
(57.42)\end{array}$ & $103(47.25)$ & $965(58.77)$ & & \\
\hline$\|$ & $202(10.86)$ & $29(13.30)$ & $173(10.54)$ & & \\
\hline III & $218(11.72)$ & $31(14.22)$ & $187(11.39)$ & & \\
\hline IV & $372(20.00)$ & $55(25.23)$ & 317 (19.31) & & \\
\hline
\end{tabular}




\begin{tabular}{|llllll|}
\hline Variables & Total (\%) & HR (\%) & non-HR (\%) & $\chi^{2} / Z$ & $P$ \\
\hline CD4 ${ }^{+}$T-cell count (cells/ml) & $211(58$, & $156(33$, & $220(62.5$, & -3.604 & $<$ \\
& $329)$ & $294)$ & $333)$ & & 0.001 \\
\hline $\begin{array}{l}\text { Viral Load (Log10 copies/ml) } \\
\text { (Median, IQR) }\end{array}$ & $\begin{array}{l}4.89(4.37, \\
5.38)\end{array}$ & $\begin{array}{l}5.08(4.38, \\
5.60)\end{array}$ & $\begin{array}{l}4.85(4.31, \\
5.35)\end{array}$ & -3.467 & 0.001 \\
$\begin{array}{l}\text { Cotrimoxazole use before } \\
\text { baseline }\end{array}$ & & & & \\
\hline Yes & $573(30.81)$ & $75(34.40)$ & $498(30.33)$ & & \\
\hline No & 1287 & $143(65.60)$ & 1144 & \\
& $(69.19)$ & & $(69.67)$ & & \\
Total & 1860 & $218(11.72)$ & 1642 & \\
& $(100.00)$ & & $(88.28)$ & & \\
\hline
\end{tabular}

\section{Characteristics Of Art In The High-risk Group}

The time between HIV diagnosis and ART initiation was 18 days in all patients included in this study. Most were treated with the NRTI + NNRTI regimen. The time between the HIV diagnosis and ART initiation and the ART regimen were not significantly different. However, the rate of ART modification was much higher in the HR group $\left(12.84 \%\right.$ vs $\left.7.73 \% ; \chi^{2}=6.577 ; P=0.010\right)$. Additionally, the percentage of cotrimoxazole use during ART in the HR group was much higher than that in the non-HR group (40.83\% vs $25.40 \% ; \chi^{2}=23.136 ; P<0.001 ;$ Table 4).

\section{Factors Related To High-risk Events For Vf}

To determine the independent factors related to high-risk events for VF, variables significantly different between the two groups were entered into a bivariate logistic regression model, such as the marital status, transmission route, Ols in the last 3 months, WHO clinical stage, baseline CD $4^{+}$T-cell count, baseline VL, ART modification and cotrimoxazole use during ART (Table 5). The occurrence of high-risk events for VF (a score of 1 for Yes, 0 for No) was defined as the dependent variable. Compared with single patients, married or cohabiting $(A O R=0.591 ; 95 \% \mathrm{Cl}$. $0.408,0.856)$ and divorced or separated $(A O R=0.425 ; 95 \% \mathrm{Cl}$. $0.207,0.873)$ patients were negatively related to high-risk events. Patients who acquired HIV homosexually showed a negative relationship with high-risk events $(A O R=0.572 ; 95 \% \mathrm{Cl}: 0.335,0.978)$. However, patients who had ART modification were 1.728 times $(95 \% \mathrm{Cl}: 1.093,2.732)$ more likely to have high-risk events, and patients who used cotrimoxazole during ART were 1.843 times (95\% Cl: 1.271, 2.672) more likely to have high-risk events. 
Table 5

Multivariate logistic regression analysis for factors associated with virological failure related high-risk events

Table 4. Characteristics of ART in HIV/AIDS patients treated with ART in Guangxi between 2003 and 2019

\begin{tabular}{|c|c|c|c|c|c|}
\hline Variables & Total (\%) & $\mathrm{HR}(\%)$ & $\begin{array}{l}\text { non-HR } \\
(\%)\end{array}$ & $x^{2} / t$ & $P$ \\
\hline $\begin{array}{l}\text { Time between HIV diagnosis and } \\
\text { ART initiation (days) }\end{array}$ & $\begin{array}{l}18(8, \\
64.75)\end{array}$ & $\begin{array}{l}18.5(7 \\
6675)\end{array}$ & $\begin{array}{l}18(8, \\
64.25)\end{array}$ & -0.460 & 0.646 \\
\hline ART regimen at $A R T$ initiation & & & & - & 0.419 \\
\hline NRTI & $15(0.81)$ & $2(0.92)$ & $13(0.79)$ & & \\
\hline NRTI + NNRTI & $\begin{array}{l}1628 \\
(87.53)\end{array}$ & $\begin{array}{l}186 \\
(85.32)\end{array}$ & $\begin{array}{l}1442 \\
(87.82)\end{array}$ & & \\
\hline $\mathrm{NRTI}+\mathrm{PI}$ & $\begin{array}{l}164 \\
(8.82)\end{array}$ & $21(9.63)$ & $\begin{array}{l}143 \\
(8.71)\end{array}$ & & \\
\hline NRTI + INSTI & $8(0.43)$ & $0(0.00)$ & $8(0.49)$ & & \\
\hline NNRTI & $13(0.70)$ & $3(1.38)$ & $10(0.61)$ & & \\
\hline NNRTI + PI & $23(1.24)$ & $5(2.29)$ & $18(1.10)$ & & \\
\hline PI & $9(0.48)$ & $1(0.46)$ & $8(0.49)$ & & \\
\hline ART modification & & & & 6.577 & 0.010 \\
\hline Yes & $\begin{array}{l}155 \\
(8.33)\end{array}$ & $\begin{array}{l}28 \\
(12.84)\end{array}$ & $\begin{array}{l}127 \\
(7.73)\end{array}$ & & \\
\hline No & $\begin{array}{l}1705 \\
(91.67)\end{array}$ & $\begin{array}{l}190 \\
(87.16)\end{array}$ & $\begin{array}{l}1515 \\
(92.27)\end{array}$ & & \\
\hline
\end{tabular}

Times of ART modification

0.011

\begin{tabular}{|c|c|c|c|c|}
\hline 0 & $\begin{array}{l}1705 \\
(91.67)\end{array}$ & $\begin{array}{l}190 \\
(87.16)\end{array}$ & $\begin{array}{l}1515 \\
(92.27)\end{array}$ & \\
\hline 1 & $\begin{array}{l}139 \\
(7.47)\end{array}$ & $\begin{array}{l}28 \\
(12.84)\end{array}$ & $\begin{array}{l}111 \\
(6.76)\end{array}$ & \\
\hline $14(0.75)$ & $0(0.00)$ & $14(0.85)$ & & \\
\hline $2(0.11)$ & $0(0.00)$ & $2(0.12)$ & & \\
\hline ART interruption & & & - & 0.117 \\
\hline Yes & $1(0.05)$ & $1(0.46)$ & $0(0.00)$ & \\
\hline No & $\begin{array}{l}1859 \\
(99.95)\end{array}$ & $\begin{array}{l}217 \\
(99.54)\end{array}$ & $\begin{array}{l}1642 \\
(100.00)\end{array}$ & \\
\hline
\end{tabular}


Table 4. Characteristics of ART in HIV/AIDS patients treated with ART in Guangxi between 2003 and 2019

Cotrimoxazole use during ART

23.136

$<$

0.001

Yes

506

$(27.20)$

89

(40.83)

417

(25.40)

No

1354

129

1225

(72.80)

(59.17)

(74.60)

Total

1860

218

(100.00)

(11.72)

1642

B

S.E.

(88.28)

Variables

Wald

AOR (95\% Cl)

$P$
value

Marital status

Single

Married or cohabiting

$-0.527$

17.342

1

0.002

0.189

7.733

0.591 (0.408,

0.005

Divorced or separated

$-0.856$

0.368

5.428

$0.856)$

Widowed

0.117

0.280

0.175

0.425 (0.207,
$0.873)$

0.020

Unknown

1.270

0.901

1.988

1.124 (0.649, 1.947)

0.676

3.562 (0.609, 20.820)

0.159

Transmission route

\begin{tabular}{|c|c|c|c|c|c|}
\hline Heterosexual & & & 8.659 & 1 & 0.034 \\
\hline $\begin{array}{l}\text { Intravenous drug use or blood } \\
\text { exchange }\end{array}$ & 0.572 & 0.369 & 2.405 & $\begin{array}{l}1.771(0.860 \\
3.647)\end{array}$ & 0.121 \\
\hline Homosexual & -0.558 & 0.273 & 4.165 & $\begin{array}{l}0.572(0.335 \\
0.978)\end{array}$ & 0.041 \\
\hline Unknown & 0.380 & 0.423 & 0.806 & $\begin{array}{l}1.462(0.638 \\
3.351)\end{array}$ & 0.369 \\
\hline \multicolumn{6}{|l|}{ Ols in the recent 3 months } \\
\hline Yes & & & 4.407 & 1 & 0.110 \\
\hline No & -0.386 & 0.225 & 2.943 & $\begin{array}{l}0.679(0.437 \\
1.057)\end{array}$ & 0.086 \\
\hline Unknown & -1.125 & 0.777 & 2.097 & $\begin{array}{l}0.325(0.071 \\
1.488)\end{array}$ & 0.148 \\
\hline
\end{tabular}

WHO Clinical stage 


$\begin{aligned} & \text { Table 4. Characteristics of ART in HIV/AIDS patients treated with ART in Guangxi between } 2003 \text { and } \\ & 2019\end{aligned}$ I
I

\section{Discussion}

Our study reported that HIV patients with a VL greater than 200 copies $/ \mathrm{ml}$ were at a higher risk of VF and AIDS-related death. Among the ART-treated HIV patients, those who were married or cohabiting ( $A O R=$ $0.591 ; 95 \% \mathrm{Cl}$. $0.408,0.856)$ or divorced or separated $(A O R=0.425 ; 95 \% \mathrm{Cl} .0 .207,0.873)$ and acquired HIV homosexually $(A O R=0.572 ; 95 \% \mathrm{Cl}$. $0.335,0.978)$ were less likely to have high-risk events, while those who had ART modification and used cotrimoxazole during ART were 1.728 times (95\% Cl: 1.093, $2.732)$ and 1.843 times $(95 \% \mathrm{Cl}: 1.271,2.672)$ more likely to have high-risk events.

In this study, we reported that patients with VL reaching 200 copies $/ \mathrm{ml}$ after 6 months of therapy were at a higher risk of VF and AIDS-related death. A retrospective cohort study indicated that among patients with persistent LLV (PLV, defined as persistent plasma viral loads of 51-1000 copies/ml for at least 3 months), a PLV > 400 copies $/ \mathrm{mL}$ (hazard ratio $=3.3 ; 95 \%$ Cl: $1.5-7.1 ; P=0.003$ ) predicted VF ${ }^{[17]}$. Additionally, Quiros-Roldan et a ${ }^{[18]}$ reported that patients with persistent LLV (37-200 copies/ml) did not have an increased risk of death compared with those with sustained $\mathrm{VS}^{[19]}$. Therefore, these two studies may support the association between VL greater than 200 copies/ml and an increased risk of VF and AIDS-related death.

Many studies have reported that respondents who were married and/or ever married were more likely to be associated with $\mathrm{VS}^{[20,21]}$. Additionally, among individuals with a non-suppressed viral load, marriage was associated with lower odds for $\mathrm{VF}^{[22]}$. In our study, we found that married or cohabiting and divorced 
patients were negatively associated with high-risk events ( $V L>200$ copies $/ \mathrm{ml})$. Marriage ensures a stable environment and treatment support from a partner and is crucial for HIV patients ${ }^{[21]}$. Patients who are married or cohabiting show better adherence to ART. However, married patients may be more willing to reduce the chances of HIV transmission to uninfected partners; thus, they would respond to growing public health education on the importance of taking $\operatorname{ART}^{[23,24]}$. Single patients and widowed patients may have less social support and an unstable living environment, which may affect their adherence to ART. Therefore, single patients and widowed patients may be the key population to target to prevent and control high-risk events for VF and AIDS-related death.

In this study, we reported that patients who acquired HIV homosexually were less likely to have high-risk events. Similar results have been reported previously. Factors associated with a high HIV suppression rate in ART-treated AIDS patients were infection through homosexual transmission $(\mathrm{OR}=0.57 ; 95 \% \mathrm{Cl}$ : $0.35-$ $0.90)^{[25]}$. A large cohort study in Hunan, China, reported that both cumulative immunological and virological failure rates ( $10.4 \%$ and $26.4 \%$ in 48 months, respectively) were the lowest in MSM compared with other population groups ${ }^{[26]}$. Additionally, Saunder et al. ${ }^{[27]}$ reported that MSM were at a considerably lower risk of VF and less common treatment switches. An explanation for our findings may be that MSM showed better management in HIV/AIDS surveillance and treatment. In China, HIV/AIDS prevention measurements targeting MSM have led to increased earlier HIV testing and improved adherence behaviours $^{[28]}$. As the acceptance of MSM increases ${ }^{[29]}$, a supportive healthcare environment was built to ensure the accessibility of medical services to MSM infected with $\mathrm{HIV}^{[30,31]}$. MSM were diagnosed with HIV infection earlier, started ART with less advanced disease and presented earlier for care ${ }^{[27]}$. MSM were also more likely to receive regular $\mathrm{CD} 4^{+}$cell count and HIV viral load monitoring, less likely to report missing ART doses, interrupt ART, or be lost to follow-up than women who have sex with men.

Patients who had ART modification were more likely to have high-risk events. Some cohort studies have reported high rates of change in the first $A R T^{[32-34]}$. ART regimens often need to be replaced because of virological failure or toxicity or for simplification $[32,35,36]$. Approximately $29.7 \%$ of patients start ARTmodified regimens within the first year after ART initiation, with half of these changes being due to drug intolerance and/or toxicity ${ }^{[32]}$. In resource-limited settings, the rates of ART modification are lower and mainly due to virological failure ${ }^{[32-34,37]}$. Therefore, ART modification may be directly due to a higher viral load, including the high-risk event defined in this study. Different ART regimens showed different rates of modification; for example, patients on lopinavir and other protease inhibitors had higher rates of modification than those on efavirenz ${ }^{[38]}$. After appropriate ART modification, the 6-month and long-term rates of VF and drug resistance are low ${ }^{[39,40]}$. However, an unnecessary ART switch increases the risk of developing drug resistance and other poor outcomes, particularly switching to third-line ART regimens, which help to damage this last line of defence against HIV. In this study, the standards for ART modification should be strict, and proper follow-up should be conducted after ART modification to avoid the incidence of high-risk events after switching. 
Cotrimoxazole, a fixed-dose combination of trimethoprim and sulfamethoxazole, is widely used against

opportunistic infections in patients with advanced HIV disease ${ }^{[41-43]}$. Increasing availability of

cotrimoxazole has resulted in a decline in mortality in individuals living with HIV (PLHIV) ${ }^{[43,44]}$. In 2017, WHO published guidelines recommending cotrimoxazole prophylaxis to reduce morbidity and mortality among PLHIV whose CD 4 count was $\leq 350$ cells $/ \mathrm{mm}^{3}$ or at clinical stage 3 or 4 or lifelong cotrimoxazole for any CD 4 count in settings with a high prevalence of malaria or bacterial infections. In China, a national free ART programme was officially launched in 2003, and the first guidelines on cotrimoxazole were released in $2005^{[45]}$. Currently, the criteria for cotrimoxazole prophylaxis among PLHIV older than 14 years in China are a CD $4^{+}$T-cell count less than 200 cells/ $\mu \mathrm{L}$ or a total lymphocyte count less than 1200 cells/ $\mu \mathrm{L}$, WHO stage 4 disease or a history of oropharyngeal candidiasis ${ }^{[13]}$. In this study, the patients who reported cotrimoxazole utilization all had baseline $\mathrm{CD} 4^{+} \mathrm{T}$-cell counts less than $200 \mathrm{cell} / \mathrm{s} / \mathrm{L}$ and/or a high VL. Therefore, patients who used cotrimoxazole during ART were more likely to have high-risk events in this study. To the best of our knowledge, continued cotrimoxazole prophylaxis therapy can significantly reduce the risk of severe opportunistic infection in ART patients ${ }^{[46]}$. However, discontinuing cotrimoxazole use may result in an increased incidence of malaria in a malaria-endemic region ${ }^{[47]}$. Sisay M et al. ${ }^{[48]}$ reported that the wide utilization of cotrimoxazole to prevent opportunistic infection may contribute to the emergence of antimicrobial resistance. Hence, it is necessary to initiate, fine-tune and stop the utilization of cotrimoxazole.

This study has several limitations. First, because the interval between the viral load tests of all the included patients did not exceed 12 months, some patients who did not undergo viral load testing within 12 months were excluded. Thus, the representativeness of the participants was affected. Second, we did not collect data to evaluate ART adherence, which may be associated with high-risk events, VF and AIDSrelated death. Finally, an ART drug resistance test was not performed to determine its impact on high-risk events.

\section{Conclusions}

This study demonstrated that a VL greater than 200 copies/ml is a high-risk event for VF. To better prevent VF and AIDS-related death, intervention measures should be adopted to optimize the surveillance of ART in patients who are single or widowed, who have ART modification, and who used cotrimoxazole during ART.

\section{Abbreviations}

AIDS

acquired immunodeficiency syndrome

ART

antiretroviral therapy

CRIMS 
Comprehensive Response Information Management System

DHHS

the Department of Health and Human Services

HIV

Human immunodeficiency virus

HR

high-risk group

LLV

low-level viremia

Mtb

Mycobacterium tuberculosis

non-HR

non-high-risk group

Ols

opportunistic infections

PLV

persistent LLV

UNAIDS

the Joint United Nations Programme on HIV and AIDS

$\mathrm{VL}$

viral load

VF

virological failure

VS

viral suppression

WHO

the World Health Organization

\section{Declarations}

\section{Ethics approval and consent to participate}

This study was reviewed and approved by the Human Research Ethics Committee of Longtan Hospital of Guangxi Zhuang Autonomous Region (Ethical review No. 2018-006).

\section{Consent for publication}

Not applicable. 


\section{Availability of data and materials}

The datasets generated and/or analysed during the current study are not publicly available because of ethical and legal reasons but are available from the corresponding author on reasonable request.

\section{Competing interests}

The authors declare that they have no competing interests.

\section{Funding}

This study was funded by the "Thirteenth Five-Year" National Major Science and Technology Projects (2018ZX10715008-002, 2018ZX10302104-001, and 2017ZX10202101-001-006), the National Natural Science Foundation of China (NSFC, 81760602 and 81803295) and Youth Science Foundation of Guangxi Medical University (GXMUYSF201827). The funding bodies kept out of the design of the study and collection, analysis, and interpretation of data and writing the manuscript.

\section{Authors' contributions}

$\mathrm{CN}, \mathrm{HL}$ and ZM designed the study. DW, QL, XP, LH and KL contributed to data acquisition. SQ, JL and HZ took part in data clean and analysis. SQ and JL contributed to interpreting the results and preparing the manuscript. All authors revised the manuscripts critically and approved the final version for publication.

\section{Acknowledgements}

The authors acknowledge the support from all the participants.

\section{References}

1. World Health Organization. Number of people (all ages) living with HIV - Estimates by WHO region [2020-12-12]. Available from: https://apps.who.int/gho/data/view.main.22100WHO?lang=en.

2. World Health Organization. Number of new HIV infections - Estimates by WHO region [2020-12-12]. Available from: https://apps.who.int/gho/data/node.main.HIVINCIDENCE?lang=en.

3. UNAIDS. Fast-track - ending the AIDS epidemic by 2030. 2014.

4. World Health Organization. Antiretroviral therapy coverage - Estimates by WHO region [2020-12-12]. Available from: https://apps.who.int/gho/data/view.main.23300REGION?lang=en.

5. Garcia F, Romeu J, Grau I, Sambeat MA, Dalmau D, Knobel H, et al A randomized study comparing triple versus double antiretroviral therapy or no treatment in HIV-1-infected patients in very early stage 
disease: the Spanish Earth-1 study. AIDS (London, England). 1999;13:2377-88.

6. Hogg RS, Rhone SA, Yip B, Sherlock C, Conway B, Schechter MT, et al. Antiviral effect of double and triple drug combinations amongst HIV-infected adults: lessons from the implementation of viral loaddriven antiretroviral therapy. AIDS. 1998;12:279-84.

7. Assefa Y, Jerene D, Lulseged S, Ooms G, Van Damme W. Rapid scale-up of antiretroviral treatment in Ethiopia: successes and system-wide effects. PLoS Med. 2009;6:e1000056.

8. Girum T, Wasie A, Worku A. Trend of HIV/AIDS for the last 26 years and predicting achievement of the 90-90-90 HIV prevention targets by 2020 in Ethiopia: a time series analysis. BMC Infect Dis. 2018;18:320.

9. Bartlett JA. Addressing the challenges of adherence. Journal of acquired immune deficiency syndromes (1999). 2002;29 Suppl 1:S2-10.

10. Bunnell R, Ekwaru JP, Solberg P, Wamai N, Bikaako-Kajura W, Were W, et al. Changes in sexual behavior and risk of HIV transmission after antiretroviral therapy and prevention interventions in rural Uganda. AIDS (London, England). 2006;20:85-92.

11. lacob SA, lacob DG, Jugulete G. Improving the Adherence to Antiretroviral Therapy, a Difficult but Essential Task for a Successful HIV Treatment-Clinical Points of View and Practical Considerations. Front Pharmacol. 2017;8:831.

12. Nachega JB, Marconi VC, van Zyl GU, Gardner EM, Preiser W, Hong SY, et al. HIV treatment adherence, drug resistance, virologic failure: evolving concepts. Infect Disord Drug Targ. 2011;11:167-74.

13. National center for AIDS/STD control and prevention CC. National handbook of free anti-retroviral therapy for AIDS. 4 ed. Beijing: People's Medical Publishing House Co., LTD; 2016.

14. Guildelines for the use. of antiretroviral agents in adults and adolescents with HIV [cited 2020 1214]. Available from:

https://clinicalinfo.hiv.gov/sites/default/files/guidelines/documents/AdultandAdolescentGL.pdf.

15. Hermans LE, Moorhouse M, Carmona S, Grobbee DE, Hofstra LM, Richman DD, et al. Effect of HIV-1 low-level viraemia during antiretroviral therapy on treatment outcomes in WHO-guided South African treatment programmes: a multicentre cohort study. The Lancet Infectious diseases. 2018;18:188-97.

16. Ryscavage P, Kelly S, Li JZ, Harrigan PR, Taiwo B. Significance and clinical management of persistent low-level viremia and very-low-level viremia in HIV-1-infected patients. Antimicrob Agents Chemother. 2014;58:3585-98.

17. Sungkanuparph S, Groger RK, Overton ET, Fraser VJ, Powderly WG. Persistent low-level viraemia and virological failure in HIV-1-infected patients treated with highly active antiretroviral therapy. HIV medicine. 2006;7:437-41.

18. Quiros-Roldan E, Raffetti E, Castelli F, Foca E, Castelnuovo F, Di Pietro M, et al. Low-level viraemia, measured as viraemia copy-years, as a prognostic factor for medium-long-term all-cause mortality: a MASTER cohort study. J Antimicrob Chemother. 2016;71:3519-27.

19. Falasca F, De Vito C, Mazzuti L, di Carlo D, Celani L, Fimiani C, et al. Copy-Years Viremia and Risk of Virological Failure in Long-Term-Treated HIV Patients. Journal of acquired immune deficiency 
syndromes (1999). 2019;80:423-8.

20. Ustinov A, Suvorova A, Belyakov A, Makhamatova A, Levina O, Krupitsky E, et al. Psychiatric Distress, Drug Use, and HIV Viral Load Suppression in Russia. AIDS Behav. 2016;20:1603-8.

21. Riedel DJ, Stafford KA, Memiah P, Coker M, Baribwira C, Sebeza J, et al. Patient-level outcomes and virologic suppression rates in HIV-infected patients receiving antiretroviral therapy in Rwanda. Int J STD AIDS. 2018;29:861-72.

22. Haas AD, Radin E, Hakim AJ, Jahn A, Philip NM, Jonnalagadda S, et al. Prevalence of nonsuppressed viral load and associated factors among HIV-positive adults receiving antiretroviral therapy in Eswatini, Lesotho, Malawi, Zambia and Zimbabwe (2015 to 2017): results from population-based nationally representative surveys. J Int AIDS Soc. 2020;23:e25631.

23. Cohen MS, Chen YQ, McCauley M, Gamble T, Hosseinipour MC, Kumarasamy N, et al. Antiretroviral Therapy for the Prevention of HIV-1 Transmission. N Engl J Med. 2016;375:830-9.

24. Phillips TK, Clouse K, Zerbe A, Orrell C, Abrams EJ, Myer L. Linkage to care, mobility and retention of HIV-positive postpartum women in antiretroviral therapy services in South Africa. J Int AIDS Soc. 2018;21(Suppl 4):e25114.

25. Yang W, Fan P, Liang Y, Li J, Ma Y, Li N, et al [Analysis on HIV suppression effect after initiating antiretroviral treatment and related factors among AIDS patients in Henan province during 2008 and 2013]. Zhonghua yu fang yi xue za zhi [Chinese journal of preventive medicine]. 2015;49:13-20.

26. Su S, Chen X, Mao L, He J, Wei X, Jing J, et al Superior Effects of Antiretroviral Treatment among Men Who have Sex with Men Compared to Other HIV At-Risk Populations in a Large Cohort Study in Hunan, China. Int J Environ Res Public Health. 2016;13.

27. Saunders P, Goodman AL, Smith CJ, Marshall N, O'Connor JL, Lampe FC, et al. Does gender or mode of HIV acquisition affect virological response to modern antiretroviral therapy (ART)? HIV medicine. 2016;17:18-27.

28. Yan H, Yang H, Li J, Wei C, Xu J, Liu X, et al. Emerging disparity in HIV/AIDS disease progression and mortality for men who have sex with men, Jiangsu Province, China. AIDS Behav. 2014;18(Suppl 1):5-10.

29. Zhang BC, Chu QS. MSM and HIV/AIDS in China. Cell research. 2005;15:858-64.

30. Stupiansky NW, Liau A, Rosenberger J, Rosenthal SL, Tu W, Xiao S, et al. Young Men's Disclosure of Same Sex Behaviors to Healthcare Providers and the Impact on Health: Results from a US National Sample of Young Men Who Have Sex with Men. AIDS Patient Care STDs. 2017;31:342-7.

31. Ng BE, Moore D, Michelow W, Hogg R, Gustafson R, Robert W, et al. Relationship between disclosure of same-sex sexual activity to providers, HIV diagnosis and sexual health services for men who have sex with men in Vancouver, Canada. Canadian journal of public health = Revue canadienne de sante publique. 2014;105:e186-91.

32. Elzi L, Marzolini C, Furrer H, Ledergerber B, Cavassini M, Hirschel B, et al. Treatment modification in human immunodeficiency virus-infected individuals starting combination antiretroviral therapy between 2005 and 2008. Arch Intern Med. 2010;170:57-65. 
33. Keiser O, Orrell C, Egger M, Wood R, Brinkhof MW, Furrer H, et al. Public-health and individual approaches to antiretroviral therapy: township South Africa and Switzerland compared. PLoS Med. 2008;5:e148.

34. Lodwick RK, Smith CJ, Youle M, Lampe FC, Tyrer M, Bhagani S, et al. Stability of antiretroviral regimens in patients with viral suppression. AIDS. 2008;22:1039-46.

35. Thompson MA, Aberg JA, Cahn P, Montaner JS, Rizzardini G, Telenti A, et al. Antiretroviral treatment of adult HIV infection: 2010 recommendations of the International AIDS Society-USA panel. Jama. 2010;304:321-33.

36. Hammer SM, Eron JJ Jr, Reiss P, Schooley RT, Thompson MA, Walmsley S, et al. Antiretroviral treatment of adult HIV infection: 2008 recommendations of the International AIDS Society-USA panel. Jama. 2008;300:555-70.

37. Pujades-Rodriguez M, O'Brien D, Humblet P, Calmy A. Second-line antiretroviral therapy in resourcelimited settings: the experience of Medecins Sans Frontieres. AIDS (London, England). 2008;22:130512.

38. Abgrall S, Ingle SM, May MT, Costagliola D, Mercie P, Cavassini M, et al Durability of first ART regimen and risk factors for modification, interruption or death in HIV-positive patients starting ART in Europe and North America 2002-2009. AIDS (London, England). 2013;27:803-13.

39. Gunthard HF, Aberg JA, Eron JJ, Hoy JF, Telenti A, Benson CA, et al. Antiretroviral treatment of adult HIV infection: 2014 recommendations of the International Antiviral Society-USA Panel. Jama. 2014;312:410-25.

40. Pavie J, Porcher R, Torti C, Medrano J, Castagna A, Valin N, et al. Efficacy and safety of a switch to unboosted atazanavir in combination with nucleoside analogues in HIV-1-infected patients with virological suppression under antiretroviral therapy. J Antimicrob Chemother. 2011;66:2372-8.

41. Mermin J, Ekwaru JP, Liechty CA, Were W, Downing R, Ransom R, et al. Effect of co-trimoxazole prophylaxis, antiretroviral therapy, and insecticide-treated bednets on the frequency of malaria in HIV1-infected adults in Uganda: a prospective cohort study. Lancet. 2006;367:1256-61.

42. Beraud G, Pierre-Francois S, Foltzer A, Abel S, Liautaud B, Smadja D, et al. Cotrimoxazole for treatment of cerebral toxoplasmosis: an observational cohort study during 1994-2006. Am J Trop Med Hyg. 2009;80:583-7.

43. Mermin J, Lule J, Ekwaru JP, Malamba S, Downing R, Ransom R, et al. Effect of co-trimoxazole prophylaxis on morbidity, mortality, CD4-cell count, and viral load in HIV infection in rural Uganda. Lancet. 2004;364:1428-34.

44. Suthar AB, Vitoria MA, Nagata JM, Anglaret X, Mbori-Ngacha D, Sued O, et al. Co-trimoxazole prophylaxis in adults, including pregnant women, with HIV: a systematic review and meta-analysis. The lancet HIV. 2015;2:e137-50.

45. Cheng W, Wu Y, Wen Y, Ma Y, Zhao D, Dou Z, et al. Cotrimoxazole prophylaxis and antiretroviral therapy: an observational cohort study in China. Bull World Health Organ. 2015;93:152-60. 
46. Anywaine Z, Levin J, Kasirye R, Lutaakome JK, Abaasa A, Nunn A, et al. Discontinuing cotrimoxazole preventive therapy in HIV-infected adults who are stable on antiretroviral treatment in Uganda (COSTOP): A randomised placebo controlled trial. PloS one. 2018;13:e0206907.

47. Polyak CS, Yuhas K, Singa B, Khaemba M, Walson J, Richardson BA, et al. Cotrimoxazole Prophylaxis Discontinuation among Antiretroviral-Treated HIV-1-Infected Adults in Kenya: A Randomized Noninferiority Trial. PLoS Med. 2016;13:e1001934.

48. Sisay M, Bute D, Edessa D, Mengistu G, Amare F, Gashaw T, et al. Appropriateness of Cotrimoxazole Prophylactic Therapy Among HIV/AIDS Patients in Public Hospitals in Eastern Ethiopia: A Retrospective Evaluation of Clinical Practice. Front Pharmacol. 2018;9:727.

\section{Figures}

8876 HIV/AIDS patients with VL records received ART in Guangxi between 2003 and 2019

Inclusion criteria:

- Available baseline VL data before treatment initiation

- ART for 6 months and longer

- Two or more viral load records during follow-up

- the interval between viral load tests did not exceeding 12 months

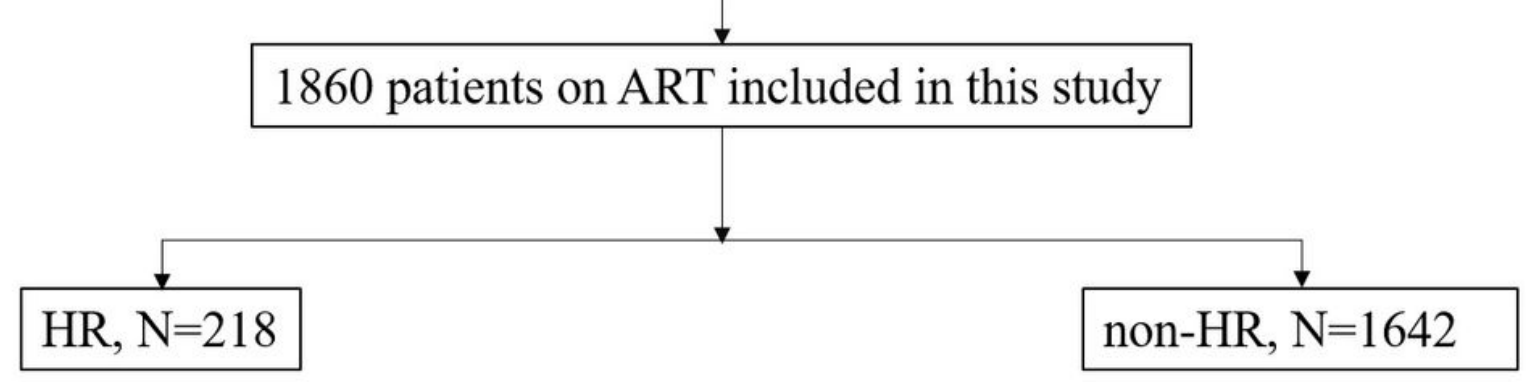

Figure 1

Flowchart of the patients' inclusion criteria. 


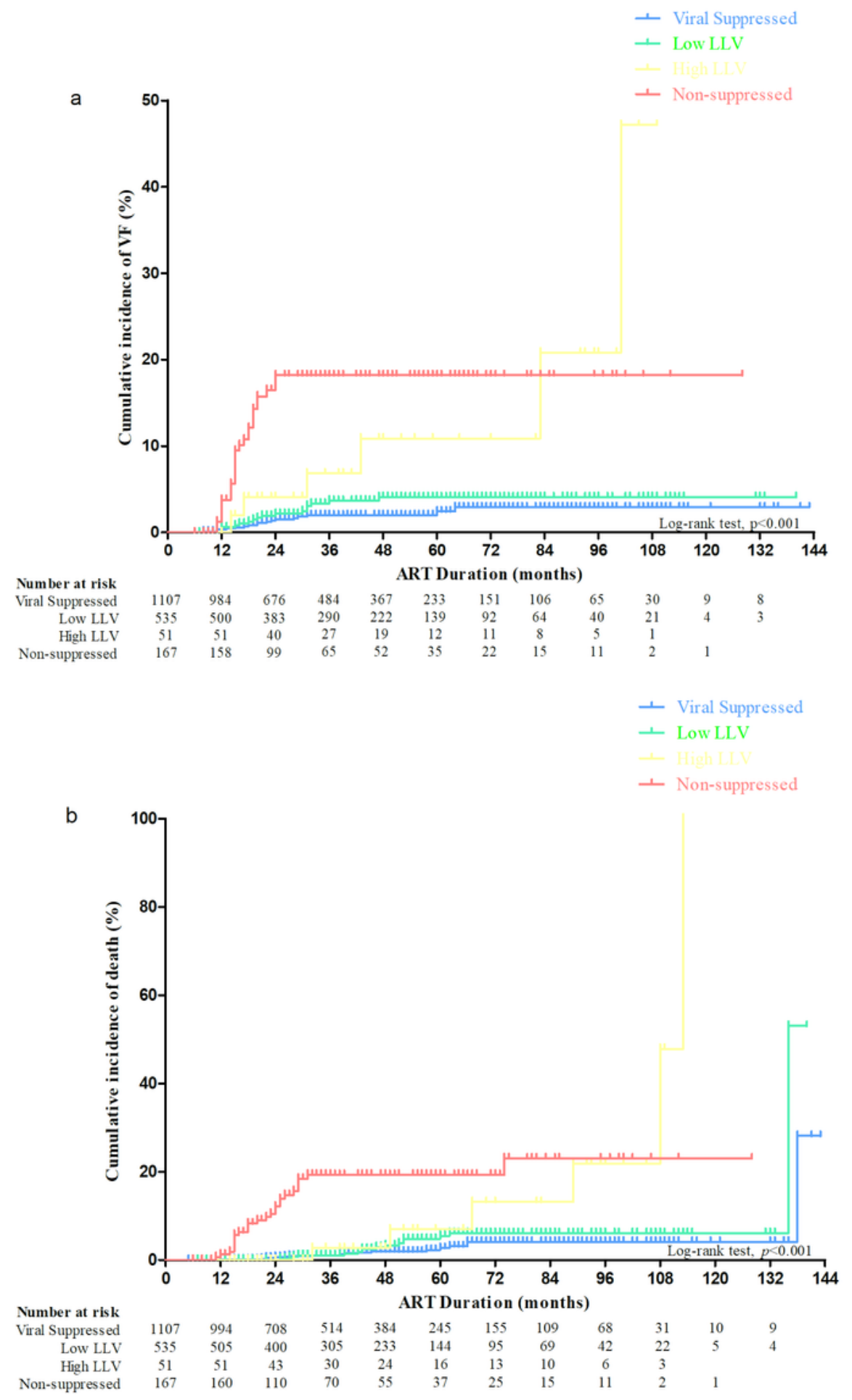

Figure 2

Cumulative incidence of VF and AIDS-related death in the different groups. a) Cumulative incidence of virological failure among different groups and b) cumulative incidence of AIDS-related death among different groups. 